\title{
Compasión, política y memoria El sentimiento moral en Max Horkheimer
}

\author{
JUAN JOSÉ SANCHEZ \\ «Mientras la moral tenga una razón de ser, habitará en ella la \\ compasión»
}

M. Horkheimer

RESUMEN. La reivindicación del sentimiento moral en el pensamiento materialista de M. Horkheimer adquiere nueva relevancia en el actual debate sobre los fundamentos y la motivación de la acción moral. Pero esa relevancia se malograría si fuera interpretada en un sentido contrario a su genuina intención. Ella no está, en efecto, en abrir la puerta a un irracionalismo romántico ni en proponer un retorno a una fundamentación premoderna, metafísica o teológica, de la moral, anticipándose a buena parte del actual pensamiento neoconservador. Su originalidad y relevancia radican más bien en que el planteamiento materialista de Horkheimer incita a una decidida superación de las morales idealistas, formales y abstractamente universales, es decir particulares, hacia una moral postidealista de la compasión y la justicia universal.

La reivindicación del sentimiento moral en el pensamiento materialista del fundador de la Escuela de Frankfurt, Max Horkheimer, parece adquirir relevancia en el marco del actual debate sobre los fundamentos y las motivaciones de la acción moral. Pero esta sorprendente actualidad corre un serio peligro: la de ser interpretada en un sentido contrario a su genuina intención. Tal sería el caso, por ejemplo, de ver en
Abstract. The claiming for the moral sentiment (feeling) in the materialist thought of M. Horkheimer becames a new significance in present discussion about the foundation and the motive of moral action. But this significance would disappoint if it was interpreted in a sense opposite to its very intention. Indeed, its signficance don't reside neither in opening the door to a romantic irrationalismus nor in propose a return to a premodern, metaphysical or theological, foundation, advancing the purpose of the present neoconsevative thought. Its originality and significance reside rather in fact that the materialist conception of moral sentiment (feeling) by Horkheimer incite to surpass the idealist, formal, and particular moral toward a postidealist moral of compassion and universal justice.

su recurso al sentimiento moral, unido - para agravar más la cosa - a la apelación a su momento teológico, un apoyo al punto de vista moral del pensamiento neoconservador comunitarista. Su singular relevancia no está, en efecto, en abrir la puerta a un irracionalismo romántico ni en proponer un retorno a una fundamentación premoderna, preilustrada, de la moral, sino en incitar a una superación dialéctica 
de las morales actuales más decididamente modernas, racionales y críticas, por ser aún excesivamente formales, idealistas, y abstractamente universales, es decir, particulares. La rehabilitación del sentimiento moral en Horkheimer apunta a una ética postidealista de la compasión y la justicia universales.

\section{El impulso moral básico: Felicidad propia, sufrimiento de los otros}

El pensamiento de Horkheimer arranca de una experiencia básica que marcó desde muy pronto su conciencia y que se convertiría para él en impulso inagotable y determinante: la experiencia de la propia felicidad entreverada con la experiencia del sufrimiento de los otros, más concretamente, la experiencia de la propia felicidad edificada sobre el sufrimiento de los otros. Fue una experiencia personal que generó en él una conciencia infeliz, inquieta y desgarrada, pero que pronto pudo articular en su pensamiento como experiencia de una contradicción fundamental, del precio de la propia felicidad, de la mano de la metafísica pesimista y la ética de la compasión de Arturo Schopenhauer, una de las primeras lecturas, junto con escritores críticos de la burguesía como Strindberg, Ibsen y Tolstoi, que cayó en sus manos. Y la conciencia de esa contradicción fundamental, del malum metaphysicum, despertó en él una especial sensibilidad para con el sufrimiento ajeno, para la desdicha de los otros, que se convertiría en un permanente móvil, en impulso moral de su pensamiento, e incluso en criterio de su sentido y verdad.

Esa especial sensibilidad estuvo además desde un principio alimentada, y significativamente modulada, por otra fuente en la que fue socializado desde el hogar: la experiencia y el mundo simbólico de la religión judía. Como más tarde él mismo recordaría, judaísmo significó para él siem- pre la esperanza en una justicia consuma$d a^{1}$, y su amigo Adorno lo corroboraba en una carta abierta dirigida a él, al recordar la actitud que le distinguía, incluso frente a él mismo y sus inquietudes estéticas: «Lo primario en ti fue la rebelión contra la injusticia» ${ }^{2}$. Esta pasión atraviesa también su pensamiento de principio a fin como un impulso moral. Uno y otro unidos constituyen lo que Adorno identificó como «el motivo central» de su pensamiento: «la salvación de lo que carece de esperanza» ${ }^{3}$, el mismo impulso que movía también su propio pensamiento (y el de Walter Benjamin, en el que se inspiraba).

Esa pasión, ese impulso moral básico, se expresó, en efecto, en los dos momentos constitutivos de su primer pensamiento: la rebelión contra el sufrimiento y la exclusión de la felicidad y la compasión con las víctimas ${ }^{4}$. Y es ese impulso el que llevó a su pensamiento a hacerse materialista, a hacerse cargo del sufrimiento de los otros y de la raíz que lo generaba. Sus escritos de los años veinte, apenas tenidos en cuenta en su interpretación, muestran claramente ese camino de su pensamiento hasta culminar en su proyecto de materialismo interdisciplinar, que inauguraría el paradigma de la teoría crítica. En ellos, aquella contradicción fundamental aparece identificada ya históricamente como contradicción de la sociedad burguesa capitalista, y su pensamiento, amasado en la metafísica de Schopenhauer, en las críticas de Kant, en la filosofía social de Hegel y, finalmente, en el materialismo histórico de Marx, realiza una ruptura significativa, un cambio de paradigma desde una «filosofía de la identidad», propia del formalismo e idealismo de la filosofía moderna y contemporánea, a una «fenomenología histórico-material» hasta culminar en una «teoría crítica-materialista de la sociedad», movida por aquel impulso moral, por «el interés en la eliminación de la injusticia social dominante» 5 . 


\section{Materialismo y moral idealista: Contra el engaño del fundamentalismo racionalista}

Es precisamente ese impulso moral el que lleva al materialismo de Horkheimer a desplegarse ante todo como crítica radical a la moral dominante, a la moral idealista de la modernidad como ideología de la sociedad burguesa y, más concretamente, a los intentos conservadores de fundamentación inmanente, pero metafísica, de la moral en la filosofía moral material y de los valores, como último bastión de aquella sociedad, ya decadente, frente al sentido peligro de relativismo moral desencadenado por Nietzsche. Esta crítica radical, sin concesiones, ha llevado a pensar que la moral, en efecto, no juega ningún papel relevante en la primera teoría crítica, que más bien queda reducida, como en el materialismo histórico que pretende actualizar en la nueva constelación histórico-social, a mera ideología de la sociedad burguesa capitalista. Y que, en todo caso, con esta crítica Horkheimer rompe todo lazo entre razón y moral y se entrega en manos de un sentimiento irracional amasado en la metafísica de la voluntad de Schopenhauer.

Pero esta lectura pasa demasiado deprisa por encima del sentido de la crítica materialista de Horkheimer. Es verdad que éste desenmascara la moral kantiana y su núcleo, el imperativo categórico, como «expresión perfecta, fiel reflejo de su tiempo», es decir, como ideología de la moderna sociedad y economía burguesa, en la medida en que ignora o no toma conciencia de su enraizamiento material y por eso encubre y legitima la escisión real entre individuo y sociedad, entre intereses individuales y bien común, entre felicidad y deber, escisión en la que consiste su «irracionalidad»y que origina «el sufrimiento de la mayoría de los hombres» ${ }^{6}$. Pero esta crítica ideológica no impide a Horkheimer en absoluto reconocer, al mismo tiempo, en esa moral un momento fundamental de verdad, en cuanto en ella se contiene una denuncia de esa misma irracionalidad — la irracionalidad de «la ley natural del beneficio económico» (MMo, 111)— y un genuino impulso moral que lleva a «la transformación de esta sociedad» (ibid., 118), a su superación en una sociedad racional en la que ella misma, esa moral idealista, pierda su razón de ser porque su verdad se ha materializado, se ha cumplido en ella (cf. ibid., 119-124).

En ningún momento cayó Horkheimer en la tentación de reducir la moral a mera ideología o de engullirla en una filosofía afirmativa de la historia, como sucedía en la «metafísica histórica» de Hegel, donde, a diferencia de la filosofía abierta de Kant, ya no jugaba ningún papel decisivo en cuanto «fuerza que impulsa hacia delante» (ibid., 127), o como no menos sucedía en el marxismo establecido, e incluso en buena parte del marxismo crítico del momento: «La moral —escribe- no es rechazada, de ningún modo, por el materialismo... como pura ideología en el sentido de falsa conciencia. Es un fenómeno humano que no se superará mientras dure la época burguesa» (ibid., 113). En este punto fue, como en otros fundamentales, que veremos, consecuentemente kantiano, incluso yendo más allá de Kant.

Porque, aun aceptando el momento de verdad del impulso moral contenido en su filosofía práctica, Horkheimer rechaza contundentemente la transfiguración racionalista, idealista, que sufre ese impulso moral en su filosofía. Que la moral sea un «hecho de la razón pura» y que se imponga como «imperativo categórico», absoluto, no es para él sino una falacia, pura ilusión, y, como ya viera y denunciara Schopenhauer, un resto teológico secularizado: una «exigencia absoluta» sólo puede «fundamentarse con sentido mediante la creencia en una conciencia absoluta» ${ }^{7}$, es decir, en la aceptación, explícita o implícita, del «supuesto teísta» ${ }^{8}$, pues, en el fondo, el teísmo es la esencia secreta de toda metafísica ${ }^{9}$. 
Todos los intentos de fundamentación últi$m a$ de la moral que no se apoyen en ese supuesto monoteísta descansan por eso, para él, en pura armonía ilusoria. Y ésa es la debilidad del proyecto kantiano de fundamentación racional de la moral.

Pero esta debilidad afecta sobre todo a los intentos conservadores, antes mencionados, de fundamentación metafísica de la moral y de los valores en Hartmann y Scheler, porque en ellos, a la ilusión armonizadora denunciada, se suma una sospecha más intensa de «engaño» que los convierte en manifiesta ideología, en un insoportable «sarcasmo» a los hombres que sufren, porque encubren y legitiman la praxis real que origina su sufrimiento e impide que se cumpla el infinito «anhelo de felicidad» que los constituye, a ellos y a todos los seres finitos (MMe, 94) ${ }^{10}$. A la vista de estos intentos manifiestamente ideológicos de «evasión metafísica», Horkheimer denuncia enérgicamente todo intento de fundamentación última racional de la moral como una ilusión y un sarcasmo a los hombres de cuya historia de sufrimiento brota el genuino impulso moral, que ese intento pretende derivar, como exigencia absoluta, de la pura razón o del cielo platónico (MMe, 68s.).

¿Significa esta crítica, esta negación, un rechazo a toda presencia de la razón en la moral, a todo lazo entre ambas y, por tanto, un «salto» desde «la ausencia de motivaciones puramente racionales - es decir, no empíricas - para la moralidad a la ausencia de toda justificación racional de sus exigencias básicas» ${ }^{11}$ ? Con otras palabras, isignifica esa negación una caída de Horkheimer, y por cierto ya del primer Horkheimer, en el irracionalismo, adelantando acaso el escepticismo radical frente a la razón y su potencial moral que la segunda generación de la teoría crítica ve -y critica - en su última etapa, tras el punto de inflexión que significaría la Dialéctica de la Ilustración?
Ciertamente, hay que reconocer que la radicalidad de su crítica materialista a todo intento de fundamentación o racionalización de la moral puede inducir a pensar en tal ruptura. Pero lo decisivo es determinar bien el sentido de esa crítica. Y éste es inequívoco. Lo que el materialista Horkheimer critica no es, en efecto, la presencia de la razón en la moral ni el lazo entre una y otra, sino la pretensión - el mitoracionalista de identificar la una con la otra, los intentos de «mistificación» del impulso moral, de transfigurarlo mediante su fundamentación racional o metafísica, en cuanto encubren su raíz en la historia de sufrimiento de los hombres e impiden que se manifieste como lo que es: el impulso de rebelión contra la injusticia y de compasión con sus víctimas, legitimando de este modo la irracionalidad existente. Por eso, su crítica sin concesiones a esos intentos estuvo acompañada siempre de una crítica no menos radical al irracionalismo o emotivismo, por cuanto también ellos deshistorizan y desmaterializan, y así desfiguran, el impulso moral, de espaldas a su raíz material ${ }^{12}$. La moral, es verdad, no se deja para Horkheimer fundamentar racionalmente, pero no por ello queda abandonada a la mera intuición o emoción. Racionalismo e irracionalismo no son para él sino dos caras del mismo proceso ideológico. El impulso moral se resiste a ser absorbido por la razón, pero no por ello es un impulso ciego. No se fundamenta ni justifica, pero sí se explica y se entiende, dice Horkheimer, «a partir de las condiciones de su surgimiento», es decir, desde la historia, desde la base material de donde brota (MMe, 64; MMo, 131), y desde ahí se descubren también «sus razones».

\section{A la base de una moral materialista: El sentimiento moral}

La moral, en efecto, no deriva para Horkheimer de la razón, como para Kant y para 
todos los intentos de su actualización, como es el caso, concretamente, de la ética del discurso o comunicativa de Habermas. El impulso moral brota para él más bien, como venimos viendo desde los primeros momentos de su pensamiento, del suelo de la historia, de la experiencia del sufrimiento que trunca el anhelo $-\mathrm{y}$ «el derecho»— de felicidad de los seres humanos finitos y perecederos. La moral hunde sus raíces en el mismo suelo, en la misma historia de sufrimiento de la que brotaron los anhelos de felicidad, la «exigencia de justicia plena, consumada», que un día tomaron cuerpo y se guardaron en la religión ${ }^{13}$. En el fondo, el mismo impulso de rebelión y la misma exigencia de justicia que ahora, despojados de su halo religioso, se expresan en el impulso moral.

Este impulso moral no es un imperativo de la razón, pero tampoco es un impulso ciego, irracional. El impulso que brota de esa experiencia material es, dice Horkheimer, un «sentimiento moral» (ibid., 127), la conciencia sensible «afectada» por la experiencia del sufrimiento de los excluidos de la felicidad, de las víctimas de la irracionalidad dominante. Horkheimer rescata el concepto kantiano de «sentimiento moral» ${ }^{14}$, pero, una vez más, haciendo de él una lectura materialista. En el origen de la moral no está la razón, como en la moral idealista, sino el sentimiento, el «pathos», la solidaridad básica con los otros seres humanos, en cuanto dignos de la felicidad pero excluidos de ella. No es, como en Kant, una facultad de la razón que inclina a obrar según el deber, pero tampoco es un mero afecto irracional, sino una afección de la conciencia sensible mediada por el reconocimiento de los otros seres finitos en su dignidad herida, en su humanidad negada. El sentimiento moral ve a los seres finitos no como «sujetos económicos», sino como "posibles miembros de una humanidad feliz» (ibid., 136). Es, por tanto, un sentimiento volcado hacia los otros y hacia el futuro, hacia «una futura vida feliz de todos los hombres» (ibid.), y ahí está su racionalidad y su carácter moral. El sentimiento es moral, en efecto, no porque sea sentimiento, irracional, sino —dice lúcidamente Horkheimer- porque «difiere de la lógica dominante», de la «ley natural del egoísmo y el interés económico» (ibid., 134), y se rebela contra ella como contra la irracionalidad que origina el sufrimiento de las mayorías. Y en esa medida es racional y pone en movimiento a la razón. Ésta es genuinamente racional cuando está atravesada por ese movimiento, por el «interés» que expresa, cuando es razón moral, razón «paciente», razón solidaria con las víctimas de la irracionalidad de la razón dominante. El sentimiento moral no es en Horkheimer irracional, sino racional «de otro modo» a como lo es la razón dominante, que no habla a favor de la moral, que no señala en la dirección en la que impulsa hacia delante el sentimiento moral, sino en el sentido del egoísmo y del poder. El sentimiento moral no se da de espaldas a la razón, pero sî implica una «ampliación de la razón» (MMo, 128) hacia una razón materialista a la que pertenece, como meollo sustancial, el propio sentimiento moral, el impulso histórico, a la vez que incondicional, de justicia plena, consumada, que lleve a cumplimiento el anhelo de felicidad de todos los seres finitos.

Con la reivindicación del sentimiento moral como base de una moral materialista progresista Horkheimer «destrona» a la razón de la moral, la abaja y relativiza, pero no para dar la palabra a su contrario, tan falso y engañoso como ella, el irracionalismo (emotivismo o decisionismo), sino para «ir más allá de ella», como la moral kantiana impulsaba más allá de ella hacia una sociedad racional y humana. $« \mathrm{El}$ paso de Kant a Schopenhauer es para Horkheimer - afirma certeramente un excelente conocedor de su filosofía moral- un avance en la autoilustración de la razón, no un retroceso al irraciona- 
lismo» ${ }^{15}$. Un avance, habría que añadir, también más allá de Schopenhauer.

La moral en Horkheimer, se dice, no es deontológica, racionalista y universalista, y ciertamente no lo es en el sentido en que lo es la moral idealista. Pero hay en esos rasgos un momento de verdad que sí comparte la moral materialista, y que indican el sentido en que ésta propone y significa su superación.

La moral materialista no es deontológica sino eudemonista. En su base no hay un mandato, una exigencia absoluta que descienda de lo alto o se imponga desde la conciencia. La moral materialista es, en este sentido, radicalmente postmetafísica y antifundamentalista. Las obligaciones, dice Horkheimer, de acuerdo con Schopenhauer, «se remontan a mandatos», en último término religiosos, que no existen. Detrás de la moral no hay ninguna «instancia suprahistórica»: «El materialismo - declara Horkheimer contra toda metafísica, expresa o larvada- no encuentra ninguna instancia transcendente a los hombres que permita distinguir entre altruismo y afán de lucro, entre bondad y crueldad, entre egoísmo y autoentrega. También la lógica permanece muda, no reconoce a la intención moral ninguna primacía» (ibid., 134). ¿Qué hay, pues, en la base de la moral, del sentimiento moral? Hay una «evidencia» que se impone al sentimiento moral también como un «hecho», pero esta vez no como un hecho de la razón, que no se da, sino como un «hecho natural»: la aspiración de los hombres, de todos los seres vivientes, a la felicidad. Evidentemente, tampoco de este hecho deriva la exigencia ética. La moral materialista no cae en otra falacia naturalista. La exigencia ética brota del reconocimiento de esa aspiración como «un derecho»y, como escribía en un texto anterior, de «la sola fe en nuestra responsabilidad» ${ }^{16}$ para con él: al sentimiento moral — dice sobriamente Horkheimer- «le parece que todos los seres vivientes tendrían un derecho a la felicidad, y no pregunta en lo más mínimo por su justificación o fundamentación» (ibid., 136; cf., MMe, 94s.) ${ }^{17}$. Pero la conciencia de ese derecho se da de bruces para el materialista con la experiencia de la injusticia dominante que lo frustra y lo niega para la mayor parte de la humanidad, y es de esta experiencia de contraste, como vimos, de donde brota el sentimiento moral como impulso de rebelión y como solidaridad con esos excluidos de la felicidad. La moral materialista es eudemonista, pero no en el sentido utilitarista o pragmatista, que gira en torno al propio sujeto - ahora de nuevo sospechosamente actual-, sino en el mejor sentido materialista del derecho de todos a la felicidad que da la primacía al derecho pendiente de los excluidos de ella. El sentimiento moral es, decíamos, un sentimiento volcado sobre los otros. Y ahí conserva, como veremos más adelante, el momento de verdad de la incondicionalidad de la moral deontológica.

Ese momento, en efecto, va ligado al carácter universal de la moral, y éste se cumple en la moral materialista también de un modo original. El sentimiento moral, decía Horkheimer, desea «a todos, en la medida en que son hombres», el cumplimiento de su constitutivo anhelo de felicidad y el pleno desarrollo de sus potencialidades. El sentimiento moral apunta «a una humanidad feliz» (MMo, 136). Pero justamente por eso es estrictamente individualista; no, claro es, una vez más, en sentido utilitarista o pragmatista, sino en el mejor sentido kantiano de que ninguna totalidad, sino sólo los individuos, finitos y perecederos, merecen «el honor de valer como objetivo absoluto», como fin (ibid., 126). Ahora bien, es por esta misma razón por la que el sentimiento moral y con él la moral materialista están volcados sobre los otros, sobre los excluidos de la felicidad. Porque la moral ha de regir para todos es por lo que el sentimiento moral está volcado sobre los otros, por lo que da prioridad a los que no gozan de su derecho a la felicidad, a las víctimas de la realidad 
inmoral. Mientras existan excluidos, lo moral no coincide con lo universalmente válido y aceptado. La universalidad de la moral se cumple a través de la parcialidad del sentimiento moral a favor de los excluidos de esa universalidad. La moral materialista es universalista siendo partidaria.

$\mathrm{Y}$ es, finalmente, por este mismo motivo por lo que el sentimiento moral se desvía de la «ley natural» del egoísmo y no coincide sin más con la razón. Mientras haya excluidos de la felicidad la razón no será universal y, consiguientemente, lo moral en el sentimiento moral no coincidirá con lo racionalmente fundamentado, sino más bien con el impulso que lleva a esa razón más allá de sí misma hacia un futuro feliz para todos. Como afirma Schnädelbach, «lo moral en la moral es precisamente lo no fundamentable» ${ }^{18}$. Por eso, la moral tiene lugar para Horkheimer sólo allí donde los hombres se atienen a «los sentimientos de indignación, compasión, amor y solidaridad» (ibid., 64) sin necesidad de apelar a una razón absoluta que los fundamente, más aún, «precisamente cuando no hay suficientes motivos racionales para sentir de ese modo» ${ }^{19}$. La moral materialista no es racionalista, pero en cuanto tal impulso -y sólo en ese sentido- el sentimiento moral es genuinamente racional. Es racional negativamente, en cuanto crítica del «mito racionalista» de que lo racionalmente establecido, lo que «tiene poder», es ya lo bueno (ibid., 153).

En una realidad histórica y social que excluye de la felicidad a la mayor parte de la humanidad, el sentimiento moral se expresa y actualiza por eso, para Horkheimer, fundamentalmente en dos formas históricas: la compasión y la política.

\section{Una ética compasiva: La solidaridad} con las víctimas de la irracionalidad

El sentimiento moral, que brota, según hemos visto, de la experiencia de sufri- miento y sinsentido que frustra el anhelo de felicidad de las mayorías, se expresa ante todo como compasión. Com-pasión o conciencia sensible de solidaridad básica con los que soportan el peso de la historia de progreso y felicidad y no son sujetos de moral, «legisladores» como requería Kant, sino objetos sometidos al poder natural, al caos, a la irracionalidad: «Vemos a los hombres no como sujetos de su destino, sino como objetos de un ciego acontecer natural, y la respuesta del sentimiento moral es la compasión» (MMo, 137s.).

El sentimiento moral no brota de la razón abstracta, sino del suelo de la historia. Por eso se entiende, dice Horkheimer, que este sentimiento básico de la compasión apenas juegue un papel relevante en la ética de Kant. Embriagado como estaba con el fulgor optimista de los comienzos de la modernidad ilustrada, Kant pudo aún esperar del «progreso ininterrumpido de la libre competencia» el cumplimiento del derecho universal a la felicidad (ibid., 138). Menos se entiende ya que Marx, y sobre todo el marxismo establecido, pasaran por encima de él con demasiada rapidez, movidos más por la lógica del poder o por una dialéctica dogmática que por el «pathos» del sufrimiento de los excluidos de la felicidad. Pero ni siquiera en tiempos de Kant, incide certeramente Horkheimer, «era separable la compasión de la moral» (ibid., 138). Mientras la moral tenga «una razón de existir», es decir, mientras la historia sea para una mayoría de la humanidad historia de sufrimiento y esas mayorías queden fuera de la felicidad, en ella «habitará la compasión» (ibid., 139). La compasión no está sólo en el origen de la moral, en su base, como el humus que abre su espacio. En cuanto sentimiento de solidaridad con los seres humanos excluidos de la felicidad y por tanto heridos, negados en su humanidad, en su dignidad, es un impulso que la atraviesa de parte a parte, mientras tenga razón de existir. La moral materialista es 
constitutivamente moral compasiva. La compasión no es un «complemento» de la moral, un añadido a la justicia, como «cuidado» ofrecido a los sujetos vulnerables y vulnerados. La compasión es una dimensión constitutiva de la moral materialista que hunde sus raíces en la historia y se hace cargo de la injusticia y el sufrimiento, que no sólo vulneran a algunos individuos de la comunidad humana, sino que los excluye de esa comunidad y niega su humanidad. En ese sentido, la compasión abre la moral, como muy bien ha visto R. Mate, a una genuina intersubjetividad, que, a la vista de la asimetría de la realidad irracional excluyente, no puede ser sino «asimétrica» ${ }^{20}$. El olvido de este momento básico, de esa dimensión fundamental, reduce peligrosamente la moral a un acuerdo entre los felices, a «ideología de la relativa prosperidad» ${ }^{21}$, negando la genuina universalidad, es decir, su verdad.

Pero el sentimiento moral de la compasión no sólo está en el origen de y acompaña a la moral mientras tenga una razón de existir, sino que incluso - afirma Horkheimer- «puede sobrevivirla», pues el humus del que brota, el «sufrimiento y la muerte», sigue presente en la naturaleza, en el mundo animal, y la solidaridad de los hombres es sólo «una parte de la solidaridad de la vida como tal» (MMo, 139). Hay una comunidad básica de vida entre los seres humanos y los animales, que Schopenhauer acertó a desvelar y reivindicar: un "parentesco entre su felicidad y su sufrimiento y la vida de los animales» (ibid.). Y de esa comunidad brota de forma natural aquel sentimiento de solidaridad, de compasión, también básica, a la vista de la vida truncada en los otros seres finitos.

El sentimiento de la compasión es la base y a la vez la expresión de la moral materialista en cuanto moral eudemonista, moral de la felicidad y la vida lograda. El sentimiento de la compasión quiere tomar absolutamente — incondicionalmente-en serio el imperativo kantiano de valorar al hombre como fin, no como medio, y por eso se aferra a - y afirma- su anhelo de felicidad y se rebela ante la realidad irracional que lo frustra; de este modo abre la moral, a través del camino de una solidaridad asimétrica, partidaria, al horizonte de una genuina universalidad sin exclusiones. El sentimiento de la compasión impide así, finalmente, que la moral idealista confunda lo racionalmente fundado sin más con lo justo y lo bueno y obliga a la razón a hacerse material y crítica, y a la moral a ser moral política, praxis histórica. La moral compasiva es por eso, dice Horkheimer, una moral política.

\section{Una moral política: \\ El futuro de una humanidad feliz}

El sentimiento moral se hace política porque, como veíamos, desea a todos los hombres una vida feliz (ibid., 136), y justamente ése es, dice Horkheimer con todos los grandes filósofos morales, el fin de la política (ibid., 139). La moral materialista es, frente a toda moral formalista, una moral del bien, de la vida buena. Es una ética material, pero no una ética de la Sittlichkeit, una ética afirmativa, sino una ética crítica y negativa de la vida buena.

Más arriba veíamos cómo Horkheimer hizo desde muy pronto una lectura materialista de la ética kantiana, reivindicando en ella la importancia de la praxis transformadora frente a los intentos conservadores, y reaccionarios por irracionales, de establecer una ética material de los valores por parte de Hartmann y Scheler para frenar el peligro de relativismo moral desencadenado por la crítica radical de Nietzsche. Para Kant, reconocía Horkheimer, la realización de la moral no era en modo alguno una ilusión, sino «la finalidad de la política» (ibid., 122). Este reconocimiento iba, sin embargo, acompañado de una crítica abierta y decidida al idealismo y al 
optimismo de Kant, quien, lo mismo que pudo desplegar su ética al margen de la compasión, pensó «el futuro de una humanidad feliz», del reino de los fines, como actualización de la utopía burguesa. Y ahí se equivocó. A Kant le faltó «una teoría materialista de la sociedad» (ibid., 123).

Eso es justamente lo que pretende ser su teoría crítica. En ésta, decíamos, no encontramos una filosofía moral desarrollada, pero no porque la moral no tuviera en ella relevancia, sino, más bien al contrario, porque toda ella no es y no se entiende más que como «un único juicio existencial desplegado» ${ }^{22}$ sobre la sociedad burguesa dominante, una teoría crítica movida por aquel impulso moral que brota de la historia del sufrimiento y se reproduce espontáneamente en aquella parte de la humanidad que lleva sobre sí el peso de esa historia, los excluidos de la felicidad, las víctimas de la irracionalidad dominante, y que ahora hereda ella como «interés en la superación de la injusticia social» ${ }^{23}$ que origina esa historia de sufrimiento y trunca el anhelo de felicidad de las mayorías. En una situación desgarrada, irracional, excluyente, donde la moral tiene una razón de existir y donde el sentimiento de compasión la habita como momento de verdad, la moral se hace política y la teoría, añade Horkheimer, no puede ser «afirmativa», sino crítica, lo mismo que la acción que ella articula no puede ser «productiva», sino negativa, transformadora y superadora ${ }^{24}$.

El sentimiento moral alcanza de este modo en la teoría crítica, a través del interés, el horizonte y la dimensión de la universalidad que lo liga a la racionalidad. Pero lo hace de forma crítica y negativa. El sentimiento moral, el interés, no es inmanente a la razón abstracta, como pensaba Kant, sino que brota, como hemos visto, en los individuos concretos, históricos, y es, como éstos, histórico y contingente. Pero no por ello es meramente subjetivo, como pensaba Max Weber (cf.,
MMo, 155). El interés es histórico y contingente, pero al convertirse en impulso de la razón, al ser «heredado» por la teoría, queda ligado a las ideas de la Modernidad, libertad, igualdad y justicia, como rasgos de la «sociedad racional» que la moral «anticipa como necesaria orientación» de la praxis, como horizonte de universalidad (ibid., 140). Pero queda ligado crítica y negativamente: como negación de la realidad irracional que las niega.

La ética materialista de Horkheimer es una ética material, no formal, una ética del bien y de la vida buena, pero no por ello es una ética de la Sittlichkeit dominante, sino, muy al contrario, una ética de la felicidad pendiente. Y por eso es - a distancia tanto de las éticas formalistas como de las neoaristotélicas conservadoras - una ética política. La moral no está en ella desligada, como en la ética formal, de «los problemas que acucian a la humanidad», sino que brota de ellos y, por tanto, no está desligada de la realización de la moral, ni la cuestión de la justicia desligada del derecho a la felicidad. Más bien se decide en ella la moral en la praxis que lleve a cumplimiento ese derecho, en los impulsos que apunten en esa dirección, no en la dirección de la lógica dominante, de la ley natural del egoísmo y del poder. En ello consistía, en efecto, como veíamos, lo moral del sentimiento moral.

En la etapa más radical de su pensamiento, finales de los años veinte hasta mediados de los treinta, y a la vista de la amenaza de la barbarie nazi, Horkheimer se pronuncia decididamente a favor del socialismo. En los apasionados aforismos de esa época Horkheimer cifra la moral justamente en «la realización del socialismo» ${ }^{25}$. Pero en ningún momento llega a caer en el dogmatismo de confundir la moral con una praxis concreta dominante. Moral y poder, felicidad y poder, siempre estuvieron en su pensamiento profundamente disociados. Allí mismo, en esos aforismos radicales, y siendo fiel a una 
postura que venía manteniendo desde sus primeros escritos, Horkheimer denuncia con la misma fuerza que a la Sittlichkeit burguesa la praxis materialista pervertida en una nueva religión, en «ideología de la relativa prosperidad», en un nuevo poder, en el mito de todos los vencedores ${ }^{26}$. La moral es para él justamente la fuerza, el impulso «que empuja hacia delante» (ibid., 127) e impide al pensamiento ceder ante el poder. Su horizonte no es lo que triunfa en la historia, sino la idea de «una humanidad feliz» (ibid., 136).

Pero Horkheimer no sólo no cedió a la seducción del poder. Tampoco cedió a la tentación de dibujar positivamente la futura «sociedad racional». Lejos aún del actual pluralismo irreductible de cosmovisiones, Horkheimer fue ya entonces muy consciente de la enorme «diversidad» de concepciones de «la situación justa» (ibid., 145), de la vida buena. La moral materialista es radicalmente histórica y, por tanto, consecuentemente postmetafísica. Por eso no sacraliza sus contenidos. La moral materialista es una moral material, pero no una filosofía materialista afirmativa de la historia. Justamente por ser material es, como decíamos, no afirmativa, sino crítica y negativa. La idea de vida buena no le viene dada ni de una «revelación» ni de una razón autónoma abstracta, sino que se configura a partir de «la miseria del presente» (ibid., 136), de la negación de la injusticia existente. Hay, sin embargo, un horizonte común a todas las ideas de vida buena, que es determinante para la moral materialista: todas ellas — afirma Horkheimer- apuntan a la felicidad sin exclusiones, a que la felicidad no se reparta arbitrariamente, a la reconciliación de justicia y felicidad (ibid., 145), es decir, al mismo horizonte al que apuntaba - y hacia el que impulsaba- el sentimiento moral. Por eso no es la moral, sino más bien la realidad inmoral, «la desigualdad social dominan- te», la que necesita una «fundamentación racional» (ibid.).

La moral materialista de Horkheimer es, como se reconoce, claramente deudora de la ética compasiva de Schopenhauer. Pero tanto en cuanto ética compasiva como, sobre todo, en cuanto ética política la concepción de Horkheimer se desmarca no menos decisivamente de la de su mentor. Como indicaba al inicio de este trabajo, hay otra fuente más originaria del pensamiento de Horkheimer que la metafísica «pesimista y buena» —como él mismo decía- de Schopenhauer. Es la experiencia mediatizada del judaísmo. Éste se materializó y condensó para él, como vimos, en el anhelo de justicia consumada. Y este impulso palpita, una vez más materializado y secularizado, en el sentimiento moral, dando a sus dos expresiones históricas, la compasión y la política, el sesgo y la dinámica que los caracteriza. Tanto la compasión como la política están en su pensamiento materialista, como hemos podido comprobar, impulsadas por aquel anhelo inagotable y por eso bajo el signo inequívoco de la solidaridad con los excluidos de la felicidad, con las víctimas de la injusticia dominante, con los otros. Y esta dinámica inconfundible de su idea de la moral es reforzada, además, por otra convicción que bebe de la misma fuente y que se entrelaza con la anterior: el respeto por la transcendencia radical del Absoluto contenido en la tradicional prohibición de las imágenes, de dar nombre al Innombrable ${ }^{27}$. Efectivamente, la radical «sobriedad metafísica» del materialismo de Horkheimer y concretamente de su ética política tiene que ver tanto con aquel impulso originario e inagotable del anhelo de justicia consumada como con este profundo respeto a la transcendencia, materializado y secularizado también en la negativa consecuente de Horkheimer a dibujar o dar nombre al bien, a la vida buena, a la sociedad justa y racional, a «la humanidad feliz». Sólo por el camino de la crítica y 
la negación fue capaz de apuntar a ese horizonte. También ahí, en esa negativa, es su moral materialista radicalmente postmetafísica.

\section{La felicidad pendiente e irreparable: Sentimiento moral, duelo y memoria}

La moral materialista de Horkheimer es ciertamente postmetafísica, pero ello no quiere decir que sea, como a veces se interpreta, anti-metafísica, incluso anti-filosófica, en el sentido de positivista ${ }^{28}$, ni tampoco que relegue al rincón del olvido, como meros restos de la superada metafísica, las cuestiones que precisamente las condiciones postmetafísicas, la conciencia de la radical historicidad y finitud humanas y los límites de la mera razón, se le plantean de forma imperiosa ante el hecho de la felicidad pendiente de los excluidos de la vida buena.

El mismo sentimiento moral que debía quedar superado con la realización de esa idea, en la sociedad racional, junto con la conciencia de la radical finitud de los seres humanos, impidió, en efecto, que la ética materialista de Horkheimer cayera en el triunfalismo del mito de una sociedad transparente. El sentido de la justicia plena, universal, inmanente al sentimiento moral como herencia de la religión, del judaísmo y del cristianismo, abre para Horkheimer, también para el primer Horkheimer revolucionariamente crítico, un insoslayable interrogante sobre cualquier proyecto político, sobre cualquier idea de vida buena con pretensiones de plenitud. Esos dos elementos constitutivos de la moral materialista conferían a ésta un sentido agudo, singular, de la definitividad de la historia, que la obligaba, a diferencia de cualquier moral idealista, y por supuesto de toda moral teológica, «a rastrear incluso la más pequeña posibilidad o esperanza para los hombres en la inmanencia y a aferrarse a ella con toda su energía» ${ }^{29}$. La moral materialista es una moral de la inmanencia radical, pero justamente por ello es una moral que se toma absolutamente en serio la definitividad de la inmanencia y rechaza enérgicamente cualquier intento - teológico o idealista - de «bagatelizarla» o de «neutralizar» sus interrogantes pendientes. Algo muy serio para ella estaba en juego en ese límite como para dejar la palabra o a la «evasión metafísica» o al optimismo de los que triunfan en la historia: la reconciliación de la historia de sufrimiento que atraviesa la inmanencia y el cumplimiento del anhelo de felicidad una y otra vez truncado de las víctimas de esa historia. Por eso, la moral política no culmina para Horkheimer nunca, ni en este primer período, en la afirmación. Cualquier futuro mejor, cualquier «situación justa» llega ya tarde porque, argumenta, «la humanidad que de (ellos) emerja no podrá ayudar ya a aquellos que quedaron en la cuneta» ${ }^{30}$ La moral política no culmina en la afirmación, sino en la asunción de la radical finitud y, por tanto, de la irreversible definitividad de la inmanencia que, a la vista de tanto anhelo no cumplido, truncado, de felicidad, a la vista de tanto grito quebrado de las víctimas de esa misma inmanencia, lleva en sí una nota profunda e imborrable de tristeza, de duelo ${ }^{31}$, en la que guarda la memoria de los excluidos de la felicidad y, con ella, lo mejor del impulso que puso en movimiento el sentimiento moral. El materialista, dice Horkheimer, sabe que el anhelo infinito de felicidad que puso en marcha este sentimiento no se puede cumplir, queda truncado definitivamente con la muerte y no encuentra eco en el silencio del universo. En esa situación el sentimiento moral roza la desesperación, como bien supieron de ello los grandes filósofos morales Kant, Voltaire y Tolstoi, y se ve confrontado con el horizonte de la religión, con el sueño de una justicia transcendente capaz de reparar la felicidad irreparablemente truncada de las víctimas. Pero, anclado como está 
en la tierra, en el suelo de la historia, y finito y perecedero como los sujetos en los que brota, el sentimiento moral no es capaz de traspasar el límite de su propia finitud y al vértigo de la desesperación sólo puede responder con aquella nota de duelo metafísico que guarda la memoria de la felicidad malograda de las víctimas. Y esa nota confiere a la moral materialista de Horkheimer un inconfundible talante pesimista, que comparte con la moral metafísica de Schopenhauer, pero que a la vez la distancia significativamente de ésta al ser un pesimismo sostenido en nombre de los otros, en nombre, como diría Adorno, de «aquellos que carecen de esperanza».

Es desde esta perspectiva desde donde debe leerse e interpretarse el conocido debate mantenido entre Horkheimer y Walter Benjamin en 1937 en torno a la «clausura» - es decir, definitividad-o «apertura» — no definitividad- de la historia. Aun cuando, como viera con gran lucidez Adorno, a ambos movía el mismo impulso moral, la misma intención: «salvar a aquellos que carecen de esperanza», ésta, sin embargo, conducía en ambos a posturas claramente divergentes. Mientras que para Benjamin la memoria es capaz de «abrir» - modificar - lo que la historia ha «cerrado» — sellado- definitivamente, a saber: el sufrimiento y la esperanza truncada de las víctimas; para Horkheimer eso era, tomado en serio, abiertamente teología, afirmación imposible para un pensamiento consecuentemente materialista. A lo que Benjamin nada tuvo que objetar, sino más bien confirmar que, en efecto, en la memoria hacemos una experiencia «que nos prohíbe concebir la historia por principio de forma a-teológica» ${ }^{32}$. Pero la negativa de Horkheimer a dar el paso a esa afirmación sólo se entiende en todo su sentido si no se pierde vista, al interpretarla, la intención crítica que la anima. En verdad, es una negativa fruto de un pensamiento transido de materialismo, pero, como hemos mostrado, éste no fue nunca para Horkheimer una cuestión meramente ideológica, sino siempre una cuestión de justicia, y así, su negativa consecuente estuvo motivada por el inequívoco respeto a la esperanza truncada, y por tanto de la dignidad dañada, de las víctimas. De ahí que no fuera una simple negativa fría y neutra del materialista, como a veces se interpreta ${ }^{33}$, sino una toma de postura contrafáctica, impulsada por el mismo sentimiento moral de la compasión que hemos encontrado a la base de la moral materialista política. Ése es el sentido de la aclaración con la que Horkheimer justifica su reserva a la postura de Benjamin: «La afirmación de que la historia no está cerrada, concluida, es idealista si no asume y conserva en sí el momento de su clausura, de su definitividad. La injusticia pasada sucedió ya y es definitiva. Los abatidos están realmente vencidos» 34 .

Por tanto, el sentimiento moral, que, según hemos visto, «precede» y «acompaña» a la razón crítica, también la «sobrepasa», impulsándola más allá de sí misma, sin por ello renunciar a ella en ningún momento, sin rebasar, a pesar de todo, los límites de la finitud, la frontera de la inmanencia. En esa situación aporética el sentimiento moral se expresa en una compasión anamnética, teñida de duelo, en una solidaridad pesimista que preserva la memoria de aquella felicidad pendiente sin cuyo cumplimiento no cabe pensar para Horkheimer ninguna idea del bien, de la justicia, de la vida buena. Esa solidaridad teñida de duelo no es sino la radicalización máxima del sentimiento moral de la com-pasión: la compasión con los excluidos históricamente de la felicidad se convierte (y culmina en) la compasión con los definitivamente excluidos de la «humanidad feliz». Y esta com-pasión se hace memoria que guarda el derecho pendiente de esos «humillados y hundidos» y preserva a la moral de pervertirse en «ideología de la relativa prosperidad». Sólo una felicidad que contenga en sí este momento de duelo 
y compasión anamnética merece para Horkheimer tal nombre. La intuición que encontramos en el origen de su pensamiento, la experiencia de la contradicción fundamental, del «precio» de la felicidad, alcanza aquí su expresión más densa y reflexiva. Y aquí se decide también la cuestión decisiva de su proyecto de teoría crítica en cuanto proyecto moral: la cuestión de la verdad. Horkheimer la afronta, hay que reconocerlo, con una honradez y radicalidad inusitadas en la tradición del materialismo en la que se inserta y pretende actualizar.

\section{La nueva amenaza: la «desmoralización» ¿Dónde anclar el sentimiento moral?}

En ningún momento, como puede deducirse de lo dicho, se hizo Horkheimer ilusiones sobre la utopía de la realización del sentimiento moral. Conforme avanzaba la década de los treinta, a la derrota del proletariado — de la «humanidad doliente»-, sujeto privilegiado del sentimiento moral, se va imponiendo en él el temor a una nueva «amenaza»: la del progresivo debilitamiento del sentimiento moral conforme avanza el dominio de la sinrazón de la razón, el poder totalitario, y conforme la razón moderna se va revelando y reduciendo a dominio y autoconservación, a razón instrumental. En esta nueva encrucijada histórica la punta de lanza de la teoría crítica cambia de dirección, de objetivo. Lo preocupante ahora no es ya tanto la desviación y desfiguración ideológica del sentimiento moral en la filosofía moral idealista (aunque, evidentemente, su crítica siguió en pie), sino la pervivencia misma del sentimiento moral, la amenaza de «desmoralización», del fin de la moral, ante la furia de la lógica de la evolución social, de la racionalización moderna. La convicción materialista de que el sentimiento moral hunde sus raíces en el suelo de la historia de sufrimiento y brota espontánea- mente en los sujetos que soportan su experiencia, convicción expresada por Horkheimer con especial fuerza frente al peligro de su transfiguración idealista, no le cegó dogmáticamente la mirada para reconocer que, en realidad, esa base era tan frágil, que el sentimiento moral había echado tan pocas raíces en los individuos y en los pueblos, y era por tanto tan débil, que corría serio peligro de ser arrollado por la corriente y ahogado por la lógica dominante (cf., MMo, 149).

En este texto, por cierto bien temprano —de 1933-, reconoce que el sentimiento moral, aunque brota espontáneo en la experiencia de la humanidad doliente, en el suelo de la historia de sufrimiento, es un impulso «heredado» de la religión, del cristianismo y, por tanto, del judaísmo, y un impulso que necesita un caldo de cultivo, unas instituciones que lo alimenten, que hagan crecer sus raíces en el interior de los individuos y los pueblos. De lo contrario, ese sentimiento corre peligro de desvirtuarse, incluso en sus sujetos privilegiados, y reducirse a mera moral burguesa, perdiendo su sustancia y su orientación, en contra de la lógica del poder económico, hacia el logro de una «humanidad feliz». En ningún momento cedió Horkheimer al espejismo de una teoría dogmática de la historia. Al sentimiento moral no lo garantiza ninguna teoría.

A partir de este momento hallamos por eso en sus escritos un motivo que es ciertamente nuevo y en cierto modo divergente del punto de vista materialista de la moral del primer período: es el motivo de buscar para el sentimiento moral un anclaje, una especie de fundamento que asegure su pervivencia, su impulso vital. En efecto, mientras que en el artículo programático «Teoría tradicional y teoría crítica» aún mantenía la visión materialista dialéctica de la historia y confiaba, por tanto, en que la idea de vida buena, de sociedad racional, es «inmanente al trabajo humano» ${ }^{35}$, es decir, brota, como el impulso moral y el 
interés en la misma, de la propia historia y de las luchas históricas que la empujan hacia ella, en el famoso "Apéndice» al mismo artículo programático parece buscar, a la vista de la cada vez más precaria situación - el progresivo aislamiento - de la teoría crítica ante la amenaza de la barbarie nazi, un mayor apoyo a esa confianza y reformula su afirmación anterior acercándose sorprendentemente a una hermenéutica antropológica: «Pues realmente está inscrito en cada hombre el objetivo de una sociedad racional» ${ }^{36}$. No obstante, inmediatamente matiza esta nueva afirmación resaltando su sentido histórico: «No es ésta una afirmación pacificadora. La realización de las posibilidades depende de las luchas históricas» ${ }^{37}$. En realidad, en este mismo sentido se había expresado ya en 1935 al afirmar que el impulso moral de rebelión contra la injusticia y de anhelo de una justicia plena «forma parte del ser humano tal como ha llegado a configurarse históricamente» ${ }^{38}$.

¿Qué significa este nuevo lenguaje? ¿Abandona Horkheimer el materialismo y cae en contradicción con su rechazo radical a toda fundamentación del sentimiento moral? Sin duda, esa búsqueda más o menos explícita de aseguramiento para la praxis histórica implica un reconocimiento implícito de que también su primer materialismo pagó tributo (aunque no dogmático) al optimismo de la filosofía materialista de la historia y adoleció de un cierto «déficit de fundamentación» de la teoría crítica, y por tanto de la moral, de la praxis histórica, como se le achaca, sobre todo desde las filas de las siguientes generaciones de la teoría crítica. Con todo, Horkheimer no sucumbió, y menos ahora, al «engaño» de la moral idealista. Pues lo que ahora se le cuestiona de forma inusitadamente radical es justamente lo que para aquella moral estaba fuera de toda duda y de toda sospecha, a saber: la razón misma. ¿Qué queda, pues, en esta encrucijada?
La situación es, en efecto, delicada. No porque estuviera en juego la coherencia de la teoría crítica, aunque también, sino porque Horkheimer veía en peligro el impulso moral que había puesto en movimiento tanto la praxis como el pensamiento materialista: el interés en la abolición de la injusticia y en la felicidad de todos los seres humanos. Y es por eso en esta encrucijada donde Horkheimer, ya desde mediados de la década de los treinta, por tanto antes de la discutida «ruptura» que supone la Dialéctica de la Ilustración, comienza a expresar su temor a que la lógica de la «ley natural» a la que se oponía el sentimiento moral, la lógica de la racionalización moderna, terminara secando también la otra fuente de la moral, su expresión más originaria: la religión: «La humanidad pierde, conforme avanza, la religión, pero esta pérdida no pasa sin dejar huella en ella...» ${ }^{39}$. Se inicia aquí - bien pronto, por tanto- la reivindicación, por parte de Horkheimer, de la religión como «fuente» de la moral. ¿No estamos acaso ante una «ruptura», más aún, ante una contradicción en su pensamiento materialista? ¿No se anuncia ya, en efecto, en ese temor una velada nostalgia por la religión, por la metafísica perdida, que terminará declarándose abiertamente en la última etapa? ¿Renuncia, por tanto, Horkheimer a su moral materialista, decididamente postmetafísica, a la altura de las condiciones de la Modernidad?

\section{Dialéctica de la Ilustración: o el triunfo del dominio sobre el sentimiento moral}

Sin duda alguna, el nuevo motivo del pensamiento de Horkheimer significa que éste ha perdido ya en esta época la esperanza en la capacidad emancipadora de la praxis revolucionaria, por tanto de la moral, en orden a conseguir una nueva sociedad racional, una humanidad feliz, y que su teoría se hace inevitablemente más «filo- 
sófica», como señalan sus críticos. ¿Significa ello, sin embargo, como sostienen esos mismos críticos, que Horkheimer pierde en estos años sombríos también la confianza en el potencial moral de la razón, que se entrega, junto con Adorno, a una crítica tan total a la razón, a un «escepticismo radical» frente a ella, que lo aboca, en la estela de Schopenhauer, a un «irracionalismo moral» $\mathrm{y}$ finalmente a un abandono de la moral en manos de la religión? ${ }^{40}$

La prueba contundente que da pie a esa lectura es, como se sabe, la polémica tesis expresada por Horkheimer y Adorno en su Dialéctica de la Ilustración según la cual los escritores sombríos de la Ilustración, de la Modernidad, pusieron el dedo en la llaga al proclamar provocativamente que es imposible derivar de la razón ningún argumento convincente a favor de la moral, en contra de la dominación y el asesinato: que la razón, en otras palabras, no está más cerca de la moral que de su negación ${ }^{41}$. Pero ésta es una afirmación sumamente compleja como para de ella deducir, sin más, una caída en el irracionalismo moral. Pues ni la Dialéctica significa una descalificación a-dialéctica de la razón moderna ni, más en concreto, el capítulo de esa obra dedicado a la moral, no casualmente escrito por Horkheimer, sanciona una ruptura, también a-dialéctica, entre razón y moral, dejando a ésta en manos del mero sentimiento irracional o en brazos de la religión. No son así de simples las cosas en esta obra de singular complejidad.

En ningún texto de la Dialéctica, en efecto, ni siquiera en los más sombríos, podrá encontrarse una a-dialéctica negación de la Modernidad ilustrada y de sus ideales emancipativos que, como hemos visto, constituían la utopía moral de la primera teoría crítica (cf., MMo, 140). Lo que Horkheimer y Adorno denuncian - como, por su parte, Walter Benjamin lo había hecho en sus famosas Tesis de filosofía de la historia - no es la razón como tal, sino la lógica de dominación y autoconservación que, según ellos, atraviesa el entero proceso de la Ilustración, de la racionalización occidental, que diría Weber, desde sus albores en el mito ( $« \mathrm{El}$ mito es ya Ilustración», DI, 56) hasta la barbarie fascista, donde culmina. La teoría crítica en cuanto crítica de la economía política burguesa se generaliza y radicaliza en una crítica de la lógica que hace que no sólo la sociedad burguesa capitalista, sino el entero proceso de «desencantamiento del mundo», de liberación de la religión y del mito - fin de la Ilustración, como proclamara $\mathrm{M}$ Weber y aceptaban Horkheimer y Adorno (DI, 59) - no avance precisamente hacia la realización de aquella utopía moral, de aquellos ideales que la expresaban, sino más bien —o mejor, a la vez- a su negación, al triunfo del capitalismo y de su lógica que todo lo reduce a mercancía, al triunfo de la razón instrumental sobre la razón moral, de la necesidad sobre la libertad: en una palabra, a la recaída en el mito.

Y lo mismo hay que afirmar del controvertido capítulo de la Dialéctica dedicado al análisis de la cuestionable relación entre Ilustración y moral (DI, 129-163). Su intención precisa no es otra que denunciar esa misma lógica, que hace que en la sociedad moderna, «enteramente desencantada», la razón como dominio, como autoconservación o egoísmo, termine triunfando sobre la utopía y el sentimiento moral, el poder sobre la felicidad, sobre el amor, la compasión y la solidaridad con los seres humanos excluidos, humillados y vencidos, con las víctimas sobre cuyos sufrimientos avanza, implacable y sordo, el progreso de la modernidad. Se trata de desenmascarar y denunciar - bien es verdad que de forma radical, conscientemente «exagerada», como el mismo Horkheimer reconocía (DI, 162) - la lógica que reduce la razón moral a razón instrumental, la lógica que, bajo el veredicto de la Ilustración, descarta y relega lo mejor del sentimiento moral: el «pathos» y la compasión, la solidaridad y el amor, como un resto de «mitología», 
la lógica que, por la misma razón, no soporta una religión que contravenga a la razón dominadora y predique, para escándalo suyo, a un «Dios crucificado», solidario con los débiles y las víctimas, pero «contradictorio» en sí mismo, como proclama — segura- Juliette, la figura implacable de la Ilustración (DI, 143-159).

¿Implica esta denuncia de Horkheimer una «ruptura» radical entre razón y sentimiento moral, como argumenta la segunda teoría crítica? Ciertamente hay que reconocer que la radicalidad - la «exageración»- de esta denuncia puede resultar desconcertante e insoportable, o al menos suscitar la duda de si no estamos, en efecto, ante una negación sin más de la capacidad moral de la razón ${ }^{42}$, más aún, ante una negación de la razón en cuanto inmoral. Pero, leída en profundidad, dialécticamente (es una ironía que la Dialéctica se lea, en la mayor parte de los casos, a-dialécticamente), se descubre que el sentido último, la intención genuina de esa crítica no es, en modo alguno, negar la razón ni su potencial moral, sino sólo su fatal reducción a mera razón formal instrumental, estratégica, a razón del dominio.

Tras esa crítica radical, exagerada, queda en pie, no obstante, la pregunta de los críticos: ¿Deja ella acaso la posibilidad de un camino racional que lleve a esa utopía? ¿No han cerrado con ella Horkheimer y Adorno toda salida histórica, toda praxis, dejando sólo la desesperada huida más allá de la historia, la salida de esta «modernidad definitivamente sumida en la oscuridad», de este «valle de lágrimas», por la vía teológica, por la religión? ${ }^{43}$ Tras la crítica radical, ¿queda, pues, espacio para la moral, o más bien sólo para la resignación y la entrega en brazos de la religión (o la estética), como sostienen sus críticos? ¿Es por esta razón por la que a partir de esta crítica radical, de esta «ruptura», Horkheimer parece agarrarse a la metafísica de Schopenhauer y a la religión en lugar de reivindicar el sentimiento moral como impulso medular de su teoría crítica?

$$
\begin{gathered}
\text { Ilustración autorreflexiva: } \\
\text { ¿punto de inflexión o reconstrucción } \\
\text { de la razón moral? }
\end{gathered}
$$

Desde comienzos de los años cuarenta, en los que cuaja esta autorreflexión de la Ilustración, Horkheimer parece, es verdad, alinearse abiertamente en la perspectiva de la filosofía de la historia negativa y contrafáctica que venía dibujando Walter Benjamin y que finalmente sintetizaría en sus famosas Tesis de filosofía de la historia. No es en absoluto casual que éstas fueran publicadas tras su muerte por Horkheimer y Adorno en memoria suya y que junto con ellas Horkheimer diera a luz un artículo, «El estado autoritario» (1942), en el que, como Benjamin, no concibiera otra salida de la historia de sufrimiento que estaba culminando en la barbarie que una «ruptura» con la lógica del progreso de la modernidad: «un salto fuera del progreso» ${ }^{44}$. ¿Es ésa, pues, la única praxis posible ante la perversión de la razón? ¿Y es una praxis histórica, moral, o estamos ya ante un salto «fuera de la historia», una salida de la inmanencia, una salida escatológica?

Como vimos, Benjamin no había tenido problemas en acudir abiertamente a la teología para auxiliar al materialismo histórico, si bien a una teología en clave materialista. Pero justamente ahí no pudo secundarlo Horkheimer. ¿Ha cambiado, pues, su planteamiento materialista a raíz de su crítica radical a la razón moderna?

Aunque esta crítica sea por momentos desconcertante, hay que responder, sin dudarlo, que su planteamiento no ha cambiado, que Horkheimer no abandona su pensamiento materialista tampoco tras esa crítica radical, que incluso se hace, como la crítica, más radicalmente materialista a pesar de todas las apariencias. De hecho, a diferencia de Benjamin, Adorno y él no conciben otra salida a la perversión de la Ilustración que una «reconstrucción de la razón», la rehabilitación de una razón moral, de una razón autorreflexiva, auto- 
crítica y anamnética que «resista» a la seducción del poder, del dominio, a la ilusión «del falso absoluto» (DI, 77, $94 \mathrm{y}$ 288s.), y sea capaz de «reorientar» el progreso hacia su fin humano, que quiebre la lógica del «olvido» y mantenga viva la «memoria» de lo oprimido y relegado en la historia, «el inextinguible y delicado impulso de la criatura hacia la expresión y la luz» (DI, 268), hacia la felicidad.

¿Es esta razón moral acaso distinta sustancialmente de la razón que sirvió de base a su primer proyecto de materialismo interdisciplinar, de su teoría crítica, de aquella razón impulsada, traspasada y sobrepasada por el sentimiento moral de la compasión y la rebelión política contra la injusticia que excluye a las mayorías de la felicidad? ¿No se trata más bien de la misma razón que, traspasada por el sentimiento moral, se desvía de la «ley natural» —de la «lógica»— del mundo moderno desencantado, pero burgués capitalista, y que se abre ilimitadamente al horizonte de la religión, no por resignación, sino por todo lo contrario: por no ceder a ella y traicionar así, bajo el pretexto de la Ilustración, de la Modernidad, el anhelo infinito de felicidad que está en su base, el derecho de las víctimas que sigue pendiente en la historia? Efectivamente, pienso que así es. La autoilustración de la Ilustración no entrega en ningún momento la razón en brazos de la religión porque le falte moral, por desmoralización, como interpretan sus críticos. Lo que ella implica es, más bien, una reconstrucción de la razón moral. Ahora como antes no cabe para Horkheimer otra expresión de la verdad, y por tanto de la moral, que «el pensamiento que niega la injusticia» (DI, 261), que resiste a los «falsos absolutos». Lo único que ahora subraya con más intensidad es que ese pensamiento, materialista y crítico como el primero, y con él la moral, contiene un «momento teológico» del que no puede despojarse so pena de perder su sustancia, de quedar reducido a «estrategia», a mera razón instrumental ${ }^{45}$.

\section{Contra la lógica del dominio: Sentimiento moral como resistencia y solidaridad}

De entrada hay que reconocer, desde luego, que el último Horkheimer no reedita su primer proyecto de «materialismo interdisciplinar», ni siquiera el de su teoría crítica de la sociedad, y que, por tanto, su crítica corre en este período un serio peligro de abstracción y se acerca a una filosofía negativa - pesimista - de la historia. En este sentido, la superación propuesta y desplegada por Habermas en su Teoría de la acción comunicativa supone un paso decisivo en la «autoilustración de la Ilustración», que dirían Horkheimer y Adorno, detrás del cual ya no es posible recaer sin retroceder racional y moralmente. Pero con la misma fuerza puede y debe afirmarse, frente a la lectura de la nueva teoría crítica, que la crítica masiva y permanente del último Horkheimer a la razón instrumental en modo alguno significa una capitulación de la razón y una caída en el irracionalismo metafísico (en la estela de Schopenhauer), ni su polémica reivindicación de la religión como impulso moral se debe a ese bien cuestionable «escepticismo con respecto a la razón» que le obliga a recurrir a la religión para fundar y sostener la moral, a «tomar prestado todo lo normativo - como afirma Habermas - de la teología mezclada y fundida con la metafísica», recayendo de este modo en las condiciones definitivamente superadas por la modernidad ${ }^{46}$.

Admitida la innegable debilidad de la última teoría crítica, la cuestión decisiva es determinar el sentido, la intención - que diría Adorno-, de su visión crítica y pesimista sobre la «lógica de la historia» que conduce inexorablemente hacia una «sociedad administrada», que frustraría definitivamente el anhelo de felicidad de las mayorías, que sellaría el triunfo definitivo del verdugo sobre las víctimas, del poder sobre la felicidad, sobre la moral. Pienso que la reivindicación de la religión — de aquel «momento teológico» inherente a la razón 
moral - por parte del último Horkheimer tiene el sentido preciso de «resistir» a esa lógica, y que, por tanto, no sólo no está en contradicción con su reivindicación del sentimiento moral en la primera etapa de su pensamiento crítico materialista, sino sustancialmente en la misma línea y obedeciendo a su misma intención originaria.

Su denuncia de la disolución de la religión, que ciertamente se hace prioritaria y reiterativa en esta última etapa, responde al temor de que «con la última huella de teología» pierda su «fundamento lógico» la moral — «el pensamiento de que el prójimo debe ser respetado»— ${ }^{47}$. Pero con esta denuncia, que sin duda parece contradecir su primera reivindicación materialista del sentimiento moral frente a su mistificación en la moral idealista, no está abogando Horkheimer por un retorno a una fundamentación religiosa, por tanto heterónoma, de la moral, lo que ciertamente estaría en manifiesta contradicción con su pensamiento materialista — con el primero y, no menos, con el último-. Esa denuncia y su positiva insistencia en «las fuentes religiosas de la moral» expresan, sin duda, un evidente cambio de acento, que a más de uno podría dar pie a situar a Horkheimer en la onda del actual pensamiento conservador en su llamada de atención ante la amenaza de desecación de aquellas fuentes en una Modernidad cegada por sus propios éxitos ${ }^{48}$. Pero con ese pensamiento no mostraría Horkheimer más sintonía que en la denuncia de los «costes» del progreso - e incluso aquí su crítica es incomparablemente más certera e inequívoca-, así como en una concepción más materialista, histórica y situada, de la razón, y por tanto de la moral, que la que sostiene la segunda teoría crítica, más kantiana e idealista incluso en su reconstrucción comunicativa como ética del discurso. Su intención es, sin embargo, otra. En ningún momento aboga Horkheimer con su denuncia y su reivindicación por un «retorno a la religión» afirmativa —como tampoco a la metafísica u ontologíaAnte todo porque sería caer en «la ilusión», por tanto en «la mentira» $(A J, 222)$, en el engaño que sigue siendo para los sujetos que sufren, para los excluidos de la felicidad, toda afirmación, toda teodi$\mathrm{cea}^{49}$. Y en segundo lugar, porque ese «falso retorno» $(A J, 227 \mathrm{~s}$.) no está movido por el impulso moral contenido en el momento de verdad de la religión, por el infinito anhelo de justicia y felicidad plenas, universales, sino más bien por su contrario, por aquella «ley natural» de la seguridad y el egoísmo a la que se oponía frontalmente el sentimiento moral. Lo que Horkheimer reivindica al apelar al «momento teológico» de la moral es lo que él mismo denomina y delimita claramente como «religión en el buen sentido», y ésta no es otra cosa que «el inextinguible, mantenido contra la realidad, de que ésta debe cambiar, que se rompa la maldición y se abra paso la justicia» (AJ, 226): es decir, el mismo impulso que se expresa en el sentimiento moral de rebelión contra la injusticia y de solidaridad o compasión con sus víctimas. Es ese impulso moral el que Horkheimer ve amenazado por la lógica de la historia, por la lógica del dominio y la autoconservación, y por el pensamiento adaptado a ella: el positivismo y el incipiente pragmatismo, a los que achaca por eso falta del sentido, de la «diferencia» moral: «El positivismo no encuentra ninguna instancia transcendente a los hombres que distinga entre altruismo y afán de lucro, entre bondad y crueldad, entre egoísmo y autoentrega.» (AJ, 166s.). Es evidente que la «instancia transcendente» aquí invocada no se refiere a la «transcendencia ontológica», metafísica o teológica, que su pensamiento materialista sigue rechazando ahora como antes ${ }^{50}$. Lo que Horkheimer reivindica con esa expresión no es otra cosa que aquel sentido moral que «transciende» toda estrategia, todo negocio al que la lógica del dominio y la autoconservación reduce en último término la moral (cf., $A J, 97)$. 
$\mathrm{Y}$ es en este mismo contexto de reivindicación del sentido moral en el que hay que situar la polémica apelación del «anhelo de lo totalmente Otro» $(A J, 165 \mathrm{~s}$.) por parte del último Horkheimer, interpretada -y sobreexplotada - por críticos y apologetas como «nostalgia» de la religión perdida y superada ${ }^{51}$. Esta interpetación suele pasar por alto con excesiva rapidez que Horkheimer habla preferentemente de «anhelo de justicia consumada» (AJ, 169, $173,194 . .$.$) y, sobre todo, que este anhelo$ coincide con aquel impulso moral reivindicado por él en su moral materialista del primer período. No se trata, en efecto, de un mero sentimiento, y menos de un sentimiento irracional, de un abandono de la fuerza moral de la razón a favor de una moral piadosa. Ese anhelo es un impulso que brota, lo mismo que el sentimiento moral, en las víctimas de la historia, «en los sujetos torturados - dice bellamente Horkheimer en el mismo sentido materialista- que no son capaces de concebir que la redención del mal infinito sea... inconcebible» (AJ, 233; cf., 203). Por eso no es un mero «impulso del corazón» ni un «deseo piadoso», sino un impulso moral, es decir, un impulso de la razón práctica, un impulso que brota y se realiza en y a través de la praxis que lo «rescata» del mundo oprimido y silenciado de las víctimas, que lo «arranca» a la realidad injusta dominante, como diría Adorno ${ }^{52}$, y lo «sostiene en contra de ella», como afirmaba Horkheimer del impulso religioso (cf., $A J, 222$ ): una praxis, por tanto, que niegue la injusticia dominante, que resista y rompa su lógica interna de dominio y autoconservación y haga posible el cumplimiento de la esperanza una y otra vez truncada de las víctimas. Se trata, pues, de un impulso práctico y contrafáctico, de un postulado de la razón práctica en el mejor sentido kantiano, traducido en clave materialista ${ }^{53}$, de un impulso que, en consecuencia, sólo es verdadero cuando está inequívocamente bajo el signo de la resistencia, de la «disidencia» y el inconformismo frente a la injusticia y su lógica de poder, y no de la resignación y la añoranza por la religión perdida o de la mera piedad del corazón, y cuando a la vez está bajo el signo inequívoco de la solidaridad con las víctimas de la injusticia y de su lógica, de la compasión con los excluidos, histórica o definitivamente, de la felicidad. El «anhelo de justicia consumada» no pertenece a quien lo formula -en este caso Horkheimer-, sino, como el sentimiento moral, a «los sujetos torturados» en los que brota y a favor de los cuales se reivindica. $\mathrm{Su}$ reivindicación por parte de Horkheimer responde por eso a la misma intención de «salvar lo que carece de esperanza», que explicitara Adorno, y a la misma convicción que sostiene la mirada de Walter Benjamin sobre la historia como historia de los vencidos: «La esperanza nos ha sido dada por (en favor de) aquellos que carecen de ella» ${ }^{54}$.

El anhelo de justicia consumada: Impulso y horizonte del sentimiento moral

La reivindicación del anhelo de justicia consumada, de lo totalmente Otro, por parte del último Horkheimer no está, pues, bajo el signo de la resignación y el retorno a la religión superada, sino bajo el signo de la defensa, de la potenciación, y de la radicalización del sentimiento moral. Es por tanto una reivindicación en profunda sintonía con su pensamiento y su moral materialistas.

Es verdad que muchas de sus afirmaciones de última hora, sobre todo las vertidas en charlas y entrevistas, sugieren la idea de que sólo la religión es capaz de salvar la moral. Pero ya hemos visto cómo su reivindicación del «momento teológico» en la moral en ningún caso implica o pretende un retorno al teísmo, a la afirmación del Absoluto, y por tanto a la religión superada en la Modernidad ilustrada, sino sólo la exigencia de que la moral, el sentimiento moral, esté atravesado por aquel anhelo (no 
afirmación) que constituyó el impulso medular que le dio origen y lo sostuvo. Lo que Horkheimer, sin embargo, no deja claro es cómo suscitar y sostener, a su vez, ese anhelo o impulso. Como hemos podido ver, Horkheimer no compartió en ningún momento el optimismo racionalista de la moral ilustrada, y en su última etapa tanto menos. La razón moral estaba para él seriamente amenazada por la razón instrumental autoconservadora. Y lo peor es que esa amenaza afectaba también a los deseos y sentimientos $\mathrm{y}$, por tanto, a la capacidad de experiencia de las mayorías finalmente situadas, integradas en la sociedad de bienestar pero crecientemente administrada (cf., AJ, 185ss.). Incluso el lenguaje se estaba vaciando de contenido, formalizando, y perdía con ello su vinculación originaria con los anhelos y los sufrimientos de los seres humanos que lo hablan. Y lo mismo sucede con el arte. ¿Qué queda, pues? ¿Dónde sostener el impulso moral? ¿Serán las religiones las que lo alimenten, la «fuente», por tanto, del sentimiento moral? Hay que reconocer que el talante del último Horkheimer es bien distinto del del apasionado materialista de los años treinta que veía brotar ese impulso espontáneamente de la experiencia de la injusticia y del sufrimiento de las mayorías. Pero esa diferencia de talante no implica un cambio en sus convicciones profundas, sino un cambio en la realidad histórica que obliga a su pensamiento, consecuentemente materialista, a reformular su visión y sus propuestas. El impulso moral sigue teniendo para él sus raíces en la tierra, pero justamente por eso está ahora amenazado por la lógica que la domina y necesita ser fortalecido. En este sentido, Horkheimer se adelantó, precisamente en cuanto materialista, a la convicción que hoy, en la frontera de la Modernidad, en la transición a una Modernidad autocrítica y reflexiva, cobra más y más fuerza, no sólo en los círculos del pensamiento conservador comunitarista, sino también, y sobre todo, en el mejor pen- samiento crítico: la razón, por sí sola, no es capaz de alimentar el sentimiento moral $^{55}$. ¿Será entonces necesaria la religión? Desde luego, si las religiones tienen una razón de existir, ésa es para Horkheimer, sin lugar a dudas, la de suscitar, sostener y cuidar ese impulso, el anhelo de justicia consumada, que alienta el sentimiento moral de la compasión y la praxis política solidaria con las víctimas (AJ, 194). Pero ello no significa, en modo alguno, que Horkheimer pretenda un retorno nostálgico a la religión, sino sólo que las religiones podrían ser fuente de genuino sentimiento moral si realizaran su momento de verdad. Posibilidad sobre la que, por cierto, no se hizo en absoluto demasiadas ilusiones... De ahí que más bien abogara por suscitar, potenciar y ampliar la conciencia de la finitud humana a escala planetaria, en la línea abierta por la metafísica de Schopenhauer, como fuente del sentimiento de solidaridad universal, que incluyera, como en la primera etapa, la solidaridad con los animales y la naturaleza. En lo cual también se adelantó, lúcidamente, a otra de las exigencias de la ética actual ${ }^{56}$.

Con todo, el problema de la moral no es para Horkheimer sólo una cuestión de motivación. El problema fundamental es la cuestión de la verdad. Y ahí, su postura vuelve a distanciarse inequívocamente tanto del optimismo racionalista de la segunda teoría crítica como, por supuesto, del pensamiento conservador. Habermas tiene razón cuando critica a Horkheimer el no haber diferenciado suficientemente entre razón instrumental y razón formal. Pero esta debilidad de su última teoría no implica un escepticismo radical con respecto a la razón. La referencia a la teología como momento de incondicionalidad de la moral no obedece en ella a una falta de confianza en la razón, sino al empeño consciente, y constante a lo largo de todo su pensamiento materialista, por concebir y defender la razón en cuanto razón moral, heredera del impulso en otro tiempo guardado en la reli- 
gión, del anhelo de justicia consumada, y de mantenerla siempre abierta al horizonte ilimitado al que apunta ese impulso: a la utopía de su cumplimiento, del «sueño de una humanidad feliz». La razón comunicativa podrá desarrollar la dimensión de incondicionalidad en su despliegue inmanente, por tanto sin recurso a Dios, a la vieja y superada teología, porque ya en sí misma, en el propio lenguaje, se da esa «transcendencia desde dentro» que la empuja en esa dirección ${ }^{57}$. Pero al final tampoco la razón comunicativa podrá evitar enfrentarse al mismo límite ante el que Horkheimer plantea, con total honradez y coherencia, la cuestión decisiva, «la pregunta de la filosofía» ( $A J, 219-226)$ : la pregunta por el futuro de la esperanza truncada de las víctimas sobre cuyos sufrimientos se ha labrado la felicidad de los felices ${ }^{58}$. Esa pregunta está, como hemos visto, en los orígenes mismos de su pensamiento y es la pregunta que acompaña y sostiene al sentimiento moral, la que pone en él la nota de incondicionalidad, y la que impide la desmoralización. La reivindicación del momento teológico en la moral no está, pues, bajo el signo de la vejez — de la resignación-, sino bajo el signo de la coherencia al mismo impulso moral que alienta su pensamiento materialista desde el principio. Y es que en aquella «pregunta de la filosofía», en aquella encrucijada aporética, se decide para Horkheimer la verdad y el sentido tanto del pensamiento como de la acción. Si esa pregunta queda sin respuesta, si la historia de sufrimiento no es reconciliada y la esperanza truncada de las víctimas no halla cumplimiento, entonces —afirma Horkheimer- «sabemos que todo el esfuerzo del pensamiento habrá sido inútil» $(A J, 225)$.

No se trata de buscar «consuelo» para sí ante los límites infranqueables de la existencia. Ni la moral ni la filosofía ofrecen consuelo alguno (cf., MMo, 152; AJ, 226).
Se trata de dar respuesta a la esperanza de los otros, de los excluidos de la felicidad. No es cuestión de resignación o consuelo, sino de justicia y solidaridad. La moral materialista no ofrece consuelo, subrayaba el materialista Horkheimer frente a la moral idealista. Y el último Horkheimer mantiene, e incluso radicaliza, esa convicción. Pocas éticas habrá tan radicalmente sobrias en este sentido como la suya (cf., AJ, 226-230). Si reivindica el momento teológico de la moral no es porque ésta haya dejado de ser materialista, sino justamente porque lo es hasta el final y se resiste a la tentación idealista de pensar la felicidad, la razón y la moral por encima o al margen de la historia de sufrimiento, de la esperanza malograda de las víctimas. Horkheimer no llegó a superar el paradigma moderno de la conciencia en el paradigma de la intersubjetividad, de la razón comunicativa. Ése es, sin duda, un límite de su moral materialista. Sin embargo, el impulso moral que puso en movimiento su pensamiento materialista llevó a éste a transcenderse en la dirección del paradigma de la intersubjetividad, incluso de forma más radical que la propia segunda teoría crítica. Pues el sentimiento moral abre la razón no a una intersubjetividad formal, simétrica, sino a la intersubjetividad herida, no realizada, pendiente. De ahí que se exprese ahora como antes, en la compasión o solidaridad con los excluidos de esa intersubjetividad, en la política que resista a la lógica del dominio y la autoconservación, que la imposibilita, y en el duelo o memoria solidaria con aquellos que han sido definitivamente excluidos de la misma, de «la humanidad feliz». La reivindicación del momento teológico en el sentimiento moral por parte del último Horkheimer no obedece a un empeño de mistificación, sino a la convicción materialista de que no hay justicia sin solidaridad, de que no hay justicia si no es universal, plena, consumada. 


\section{NOTAS}

${ }^{1}$ Cf. M. Horkheimer, Anhelo de justicia, Madrid, Trotta, 2000 , pp. 59 y ss., 235.

${ }^{2}$ Carta de 14 de febrero de 1965 recogida ahora en M. Horkheimer, Gesammelte Schriften, XVIII, Frankfurt, 1996, p. 594

${ }^{3}$ Carta a Horkheimer de 25 de febrero de 1935 recogida ahora en M. Horkheimer, Gesammelte Schriften, XV, Frankfurt, 1995, p. 328.

${ }_{4}^{4}$ Me refiero a sus escritos de juventud, M. Horkheimer, «Aus der Pubertät. Novellen und Tagesbuchblätter», en Gesammelte Schriften, I, Frankfurt, 1988.

${ }_{5} \mathrm{M}$. Horkheimer, «Traditionelle und Kritische Theorie» (1937), en Gesammelte Schriften, IV, Frankfurt, 1988, p. 216 (trad. cast. M. Horkheimer, Teoría tradicional y teoría crítica, Barcelona, Paidós, 2000, p. 77. En adelante citaré por esta edición).

${ }^{6}$ M. Horkheimer, «Materialismus und Moral» (1933), en Gesammelte Schriften, III, Frankfurt, 1988, p. 116 (trad. cast. «Materialismo y Moral», en M. Horkheimer, Materialismo, metafísica y moral, Madrid, Tecnos, 1999, p. 109. En adelante citaré por esta edición en el cuerpo mismo del texto con la sigla MMo y la referencia de página).

M. Horkheimer, «Materialismus und Metaphysik» (1933), en Gesammelte Schriften, III, cit., p. 81 (trad. cast. «Materialismo y Metafísica», en M. Horkheimer, Materialismo, metafísica y moral, cit., p. 61. En adelante citaré por esta edición en el cuerpo mismo del texto con la sigla MMe y la referencia de página).

${ }^{8}$ M. Horkheimer, «Bemerkungen zur philosophischen Anthropologie» (1935), en Gesammelte Schriften, III, cit., p. 256 (trad. cast. «Observaciones sobre la antropología filosófica», en M. Horkheimer, Teoría crítica, Buenos Aires, Amorrortu, 1974, p. 56, por la que cito).

${ }^{9}$ «La verdad eterna - afirma Horkheimer en 1936 - tiene sin Dios tan poco fundamento y sostén como el amor infinito» («Zu Theodor Haeckers Der Christ und die Geschichte», en Gesammelte Schriften, IV, cit., p. 100).

${ }^{10}$ Crítica que venía haciendo desde los años veinte frente al potencial emancipador de la filosofía práctica de Kant (cf. «Phänomenologische Wertphilosophie und Kants praktische Philosophie: Ethik als Harmonisierung der Gegenwart oder Gestaltung der $\mathrm{Zu}$ kunft» (1926), en M. Horkheimer, Gesammelte Schriften, XI, Frankfurt, 1987, pp. 142 y ss.).

${ }^{11}$ Como sostiene Th. McCarthy, «On the idea of a Critical Theory and its Relation to Philosophy», en D. C. Hoy y Th. McCarthy (eds.), Critical Theory, Cambridge, 1994, p. 27. Interpretación que es aceptada en los círculos de la segunda teoría crítica sin reservas. Es verdad que Horkheimer tiende a identificar fundamentación racional con fundamentación absoluta, como ha señalado con acierto H. Brunkhorst («Dialektischer Positivismus des Glücks. Max Horkheimers materialistische Dekonstruktion de Philosophie», Zeitschrift für philosopische Forschung, núm. 39, 1985 , p. 364), pero ello no da pie para hablar en él de positivismo ni de irracionalismo.

${ }^{12}$ Cf. por ejemplo su clarividente e inequívoco artículo «Zum Rationalismusstreit in der gegenwärtigen Philosophie», en Gesammelte Schriften, III, cit., pp. 163-220.

${ }_{13} \mathrm{M}$. Horkheimer, «Anfänge der bürgerlichen Geschichtsphilosophie» (1930), en Gesammelte Schfhriften, II, Frankfurt, 1987, p. 240 (trad. cast. «Los comienzos de la filosofía burguesa de la historia», en M. Horkheimer, Historia, metafísica y escepticismo, Madrid, Alianza, 1982, pp. 86 y ss.). En el mismo sentido, «Zu Theodor Haecker...», cit., p. 100

${ }^{14}$ Aunque no hace referencia explícita a los clásicos pasajes de la Fundamentación de la metafísica de las costumbres y de la Crítica de la razón práctica, es evidente que Horkheimer lo toma de la filosofía práctica de Kant, no de la alternativa «teoría de los sentimientos morales» de Shaftesbury, Hutcheson o Hume, aunque, como Kant, reconozca su momento crítico frente al dogmatismo racionalista [cf. «Inmanuel Kant — zum 150. Todestag» (1955), en Gesammelte Schriften, VII, Frankfurt, 1985, p. 37].

${ }^{15} \mathrm{H}$. Schnädelbach, «Max Horkheimer und die Moralphilosophie des deutschen Idealismus», en A. Schmidt y N. Altwicker (eds.), Max Horkheimer heute: Werk und Wirkung, Frankfurt, 1986, p. 61.

16 «Phänomenologische Wertphilosophie...», cit., p. 143.

${ }^{17}$ Hay en la ética materialista de Horkheimer, sin duda, una componente decisionista, en la medida en que la ética no descansa para él en ninguna metafísica (o teología) ni se sigue de la sola razón. Pero esa componente no implica en modo alguno que quede abandonada a lo irracional o meramente emocional. «Horkheimer se opone sólo a las pretensiones excesivas, es decir, idealistas, de fundamentación» (H. Schnädelbach, «Max Horkheimer und die Moralphilosophie...», cit., p. 65). Su posición estaría, pues, entre el irracionalismo y la fundamentación fuerte racional, más en sintonía con la «fundamentación débil» de la moral que ha propuesto A. Wellmer frente al propio Habermas (cf. Ética y diálogo, Barcelona, Anthropos, 1994).

${ }_{18}$ H. Schnädelbach, ibid., p. 61.

${ }^{19}$ Ibid., p. 62.

${ }^{20}$ R. Mate, La razón de los vencidos, Barcelona, Anthropos, 1991, p. 145

${ }^{21}$ M. Horkheimer, «Dämmerung» (1926-31), en Gesammelte Schriften, II, Frankfurt, 1987, p. 371 (trad cast. Ocaso, Barcelona, Anthropos, 1986, p. 83). Esta idea atraviesa los escritos de Horkheimer como un motivo crítico fundamental. Por eso, en la ausencia de este sentimiento de compasión, en la insensibilidad frente al sufrimiento de los otros, sobre todo de «los 
débiles y los pequeños», vio él siempre una de las causas de la perversión del pensamiento materialista, concretamente del marxismo (cf. por ejemplo «Späne», en M. Horkheimer, Gesammelte Schriften, XIV, Frankfurt, 1988 , pp. 247 y ss.).

${ }^{22}$ M. Horkheimer, «Teoría tradicional y teoría crítica», cit., p. 62

${ }^{23}$ Ibid., p. 77. Éste es —añade Horkheimer- el contenido del «concepto materialista de razón». Otra de las ideas fundamentales que atraviesan todos sus escritos. Volveremos sobre ella.

24 Ibid. Como ha visto bien A. Arteta, el acierto de la reivindicación del sentimiento moral en Horkheimer es haber ligado estrechamente, frente a la moral formal o idealista, la compasión y la política, la solidaridad y la superación de la injusticia (La compasión. Apología de una virtud bajo sospecha, Barcelona, Paidós, 1996, pp. 264 y ss.)

${ }_{25}$ M. Horkheimer, «Escepticismo y moral», en $\mathrm{Oca}$ so, cit., p. 51 .

${ }^{26}$ Ibid., p. 83. La resistencia a este mito es otra de las líneas de fuerza de su pensamiento $-\mathrm{y}$ de su ética-materialista.

${ }^{27}$ Es otro de los elementos configuradores de su pensamiento, como él mismo recordó en trabajos del último período (cf. «Epílogo a Portraits deutsch-jüdischer Geistesgeschichte» y «Salmo 91», en Anhelo de justicia, cit., pp. 59 y ss., 106 y ss., 235) y Adorno subrayó también en su Carta Abierta (cit., p. 594).

${ }_{28}$ Por ejemplo, H. Brunkhorst, «Dialektischer Positivismus des Glücks», cit., p. 357, en el que se apoya J. Habermas en su interpretación de la evolución del pensamiento de Horkheimer (cf. «Max Horkheimer: sobre la historia del desenvolvimiento de su obra», en Textos y contextos, Barcelona, 1996, p. 116).

${ }_{29}$ M. Horkheimer, «Zum Rationalismusstreit in der gegenwärtigen Philosophie»(1934), en Gesammelte Schriften, III, cit., p. 215.

${ }^{30}$ M. Horkheimer, Ocaso, cit., p. 170

${ }_{31}$ M. Horkheimer, «Zu Theodor Haecker...», cit., pp. 99 y ss. Otra de las convicciones centrales de su pensamiento materialista, que incide decisivamente en su idea de felicidad universal, consumada, y determina consiguientemente el horizonte de la moral. Por eso le sorprendería la práctica irrelevancia de esta idea de «duelo metafísico» — como del sentimiento de la compasión - en el pensamiento materialista de Marx y Engels (Carta a Adorno de 11 de junio de 1949, en Gesammelte Schriften, XVIII, Frankfurt, 1996, p. 50).

${ }^{32}$ W. Benjamin, «Das Passagenwerk», N, 8, 1, en Gesammelte Schriften, V.1, Frankfurt, 1982, pp. 588 y s.

${ }_{33}$ Por ejemplo, J. Habermas, «Max Horkheimer: sobre la historia...», cit., p. 128.

${ }^{34}$ Carta a W. Benjamin de 16 de marzo de 1937, en M. Horkheimer, Gesammelte Schriften, XVI, Frankfurt, 1995, p. 52.
${ }^{35}$ M. Horkheimer, «Teoría tradicional y teoría crítica», cit., p. 47

${ }^{36}$ M. Horkheimer, «Apéndice» (1937), en Teoría tradicional y teoría crítica, cit., pp. 86 y ss. Como se sabe, este apéndice lo escribió como respuesta al artículo «Teoría crítica y filosofía» que H. Marcuse publicó en la revista del Instituto tras aparecer el de Hork heimer y en el que llamaba la atención sobre un déficit de fundamentación filosófica de la teoría crítica.

${ }^{37}$ Ibid., p. 87.

${ }^{38}$ M. Horkheimer, "Gedanke zur Religión», en Gesammelte Schriften, III, cit., p. 327.

${ }^{39}$ M. Horkheimer, «Gedanke zur Religión», cit., p. 328.

${ }^{40}$ Así, sobre todo, J. Habermas en su artículo «Sobre la frase de Horkheimer: "Es inútil pretender salvar un sentido incondicional sin Dios"», en Textos y contextos, cit., pp. 133 y ss., al que haremos por eso, a partir de ahora, repetidas referencias. También A. Wellmer en Finales de partida: La modernidad irreconciliable, Valencia, 1993, pp. 240 y ss.

${ }^{41}$ Cf. M. Horkheimer y Th. Adorno, Dialéctica de la Ilustración. Fragmentos filosóficos, Madrid, Trotta, 1994, p. 163 (en adelante, citada en el cuerpo del texto con la sigla $D I$ y la referencia de página).

42 Como sostiene Habermas, «Sobre la frase de Horkheimer...», cit., p. 134.

${ }^{43}$ Como piensa A. Wellmer, Finales de partida, cit., pp. 243 y ss.

${ }^{44}$ M. Horkheimer, «Autoritärer Staat», en Gesammelte Schriften, V, Frankfurt, 1987, p. 307 (trad. cast. «El estado autoritario», en Sociedad en transición. Estudios de filosofía social, Barcelona, 1976, p. 111).

${ }^{45}$ M. Horkheimer, «Zur Kritik der instrumentellen Vernunft», en Gesammelte Schriften, VI, Frankfurt, 1991, p. 21 (trad. Cast. Crítica de la razón instrumental, Sur, Buenos Aires, 1973, p. 7).

46 J. Habermas, «Sobre la frase.....», cit., p. 136.

${ }^{47}$ M. Horkheimer, Anhelo de justicia, cit., p. 93 (en adelante, esta obra, que recoge escritos del último Horkheimer sobre moral y religión, se citará en el cuerpo del texto con la sigla $A J$ y la referencia de página).

${ }^{48}$ Desde R. Bellah, Hábitos del corazón, Madrid, Alianza, 1989, hasta Ch. Taylor, Fuentes del yo, Barcelona, Paidós, 1996, pasando por L. Kolakowski, Si Dios no existe..., Madrid, Tecnos, 1985. Hay que reconocer que el pensamiento materialista de Horkheimer siempre estuvo cerca del pensamiento conservador sensible a «los costes» del progreso... Pero su cercanía terminaba, y termina también en este caso, ahí. Su intención, como digo, es bien distinta. No hay en Horkheimer, en efecto, retorno al teísmo, pero no, como piensa Taylor (ibid., p. 528), porque su pensamiento sea enteramente «antropocéntrico y subjetivista», sino por ser materialista. Pero justamente por ser materialista, el temor ante el «declive de la fe religiosa» (ibid. p. 328) no se centra en él en las consecuencias negativas para la «identidad del yo», sino en la debilitación del impulso moral que apunta a la felicidad pendiente de los otros. 
${ }^{49}$ Sostener que la moral del último Horkheimer presupone el «concepto ontológico de transcendencia», como hace Habermas («Sobre la frase...», cit., p. 139), contradice la posición materialista fundamental de aquél según la cual en ese concepto «habita ya la mentira» (AJ, 222; cf. 226). No se puede afirmar, por tanto, que Horkheimer cae en una heteronomía preilustrada, como interpreta R. Vargas Machuca, «Ética y marxismo», en V. Camps y otros (eds.), Concepciones de la ética, Madrid, Trotta, 1992, pp. 218 y ss.

${ }^{50} \mathrm{Si}$ su materialismo no tuviera, como hemos podido comprobar, un sentido crítico y contrafáctico frente al desafío de cada situación histórica, Horkheimer habría identificado con esta argumentación, que repite literalmente, como podemos comprobar, la empleada en la primera etapa contra la moral metafísica, idealista (cf. MMo, 134), su propia ética materialista con el relativismo moral del positivismo y pragmatismo, lo que, evidentemente, no es el caso.

${ }^{51}$ En mi introducción a Anhelo de Justicia (cit., pp. 29 y ss.) he precisado el sentido de esta inquietante reivindicación de Horkheimer frente a sus críticos y apologetas.

${ }_{52}$ Th. Adorno, Minima moralia, Caracas, Monte Ávila, 1975, p. 108.

53 «La praxis ha de ser tal — afirma Horkheimer, interpretando así a Kant- que no se pueda concebir que no existe el Absoluto» [ «Inmanuel Kant — zum 150. Todestag» (1955), en Gesammelte Schriften, VII, Frankfurt, 1985, p. 40]. Esta idea del impulso moral como negación de la injusticia, medular, como vemos, en la teoría crítica, no se halla lejos del «imperativo de la disidencia» propuesto por J. Muguerza como alternativa a la fundamentación racional de la moral, de los derechos humanos («La alternativa del disenso», en Ética, disenso y derechos humanos, Madrid, 1998, pp. 11-84, esp. 58 y ss.).
${ }^{54}$ W. Benjamin, «Goethes Wahlverwandschaften», en Gesammelte Schriften, I/1, Frankfurt, 1974, p. 201. En esta decidida orientación del anhelo de justicia, como del sentimiento moral, hacia los otros, los excluidos histórica o definitivamente de la felicidad, se distancia la moral materialista de Horkheimer significativamente de la moral de la compasión de su mentor Schopenhauer, en la que la solidaridad no implica tanto el cumplimiento de la justicia cuanto la disolución de los individuos. Y también, por supuesto, del «sentimiento de solidaridad» reivindicado por el actual neopragmatismo (cf. R. Rorty, Contingencia, ironía y solidaridad, Barcelona, Paidós, 1989, pp. 207 y ss.) que más bien está impulsado por una dinámica etnocéntrica, contraria a aquella orientación del sentimiento moral. En esa orientación, la ética materialista de Horkheimer bebe más de la «otra» fuente que está en su origen, de la pasión por la justicia del mejor judaísmo.

55 Pienso, por ejemplo, en las reivindicaciones de la teología política (J. B. Metz, «Religión und Politik an den Grenzen der Moderne», en Zum Begriff der neuen politischen Theologie, Mainz, 1997, pp. 176 y ss.) y de la fuente judía del pensamiento occidental (R. Mate, Memoria de occidente, Barcelona, Anthropos, 1997).

${ }^{56}$ Por ejemplo, F. Fernández Buey, «Barbarie, tolerancia, igualdad en la diversidad», en M. Cruz (comp.) Tolerancia o barbarie, Barcelona, Gedisa, 1998, pp. 115 y ss.

57 «Sobre la frase...», cit., pp. 145 y ss.

58 También Habermas ha tomado nota de ese límite y de la aporía que representa a raíz de las críticas que le han venido de parte de teólogos críticos (cf. «iAfectan las objeciones de Hegel contra Kant también a la ética del discurso?», en Aclaraciones a la ética del discurso, Madrid, Trotta, 2000, p. 32). 